\title{
Effects of nitrogen levels on growth, yield and nitrogen use efficiency of some newly released Egyptian rice genotypes
}

https://doi.org/10.1515/opag-2018-0034

received May 28, 2018; accepted July 2, 2018

\begin{abstract}
Application of appropriate level of nitrogen fertilization is a major objective to increase nitrogen use efficiency by rice varieties. Field experiments were conducted during 2016 and 2017 growing seasons to evaluate the efficiency of varying nitrogen fertilizer rates on growth and yield parameters, along with nitrogen use efficiency of some newly released rice varieties (Sakha 108) and some promising lines GZ9399-4-1-1-3-2-2, GZ101015-1-1-1 and GZ10154-3-1-1-1. Five nitrogen levels (i.e. 0, 55, 110,165 and $220 \mathrm{~kg} \mathrm{~N} \mathrm{ha}^{-1}$ ) were used. The results from both growing seasons indicated that, Sakha 108 recorded the highest grain yield while GZ10154 and GZ10101 recorded the lowest grain yields. A linear increase in grain yield was observed with continuous rate increase of nitrogen from 0 to $220 \mathrm{~kg} \mathrm{ha}^{-1}$, while $220 \mathrm{~kg} \mathrm{~N}^{-1}$ treatment showed maximum grain yield followed by $165 \mathrm{~kg} \mathrm{~N} \mathrm{ha}^{-1}$, with control as minimum. Agronomic nitrogen use efficiency (AE) for studied rice genotypes varied significantly, and ranged from 3.63 to 32.9 and from 2.72 to $34.12 \mathrm{~kg}$ grain yield produced per kg of nitrogen applied in 2016 and 2017 respectively. Across N levels, GZ9399 recorded the highest values of $\mathrm{AE}$ for the nitrogen fertilizer rate of $165 \mathrm{~kg} \mathrm{~N} \mathrm{ha}^{-1}$ in both seasons.
\end{abstract}

Keywords: Nitrogen fertilizer, rice varieties, growth rate, rice grain yield, Agronomic efficiency

\footnotetext{
*Corresponding author: Adel M. Ghoneim, Rice Research and Training Center, Field Crops Research Institute, Agricultural Research Center, Giza, Egypt, E-mail: aghoneim@ksu.edu.sa Gewaily E.E., Marvet M.A. Osman, Rice Research and Training Center, Field Crops Research Institute, Agricultural Research Center, Giza, Egypt
}

\section{Introduction}

Rice (Oryza sativa L.) is one of the most popular field crops among other cereals in the world, being cultivated in different agro-ecosystems. Rice serves as the staple food for world's half population (FAO 2004: 87-91). Rice is a source of energy for major portion of world's population and ranks second after maize with respect to production (Manjappa and Shailaja 2014). Therefore, sustainable rice production is necessary to overcome food scarcity throughout the globe. Besides various abiotic stresses causing extensive losses to sustainable rice production, imbalanced nutrient, also leads to decreased grain yields, with marginal net returns (Zafar et al. 2018: 65-9; Wattoo et al. 2018). In Egypt, rice is a second staple food after wheat, and it is an export crop. Rice is cultivated on reclaimed saline land, which is widely spread in North delta and coastal area.

Nitrogen is essential nutrient element for rice growth and metabolic processes (Noor 2017; Ghoneim and Ebid 2015). Before making recommendations for the nitrogen fertilizer dose for any crop, one should evaluate the efficiency and optimum rate for different application levels for better growth and yield performance of each released rice variety (Noor 2017). Generally, N fertilizer recommendations in many rice-growing regions of the world follow a prescriptive approach based on generic models, without considering site-specific differences for crop N requirements (Noor 2017; Meisinger et al. 2008). Efficient use of $\mathrm{N}$ chemical fertilizers can be attained through cultural and agronomic practices. Most importantly by breeding varieties having maximum NUE, thereby reducing risks of environmental and soil water pollution with low nitrogen inputs (Noor 2017; Fageria et al. 2008; Sachiko et al. 2009). Shaiful Islam et al. (2009) found that applying optimum dose of nitrogen can save money while maintaining a safe environment. Excessive use of nitrogen fertilizer has impacts on soil and environment through residual effect. Salem (2006) reported that by maximizing 
nitrogen, all grain specimens significantly increased in weight and protein content. Ebaid and Ghanem (2000) also revealed in their study that increasing nitrogen dose up to $144 \mathrm{~kg} \mathrm{~N}^{\mathrm{N}} \mathrm{a}^{-1}$ significantly improved plant growth, yield and yield components. El-Batal et al. (2004) recorded that nitrogen application increase from 120 to $190 \mathrm{~kg} \mathrm{~N} \mathrm{ha}^{-1}$ improved plant height, panicle length, number of filled grains /panicle and grain yields significantly. Similarly, Yoseftabar (2013) found significant increase in plant growth parameters, yield traits and grain yield at the rate of 100, 200 and $300 \mathrm{~kg} \mathrm{~N} \mathrm{ha}^{-1}$.

Application of the appropriate level of nitrogen fertilizers is a major discussion with regards to economic viability of rice crop production. This study was conducted with the objectives to evaluate the efficiency of different nitrogen levels on rice growth, productivity and nitrogen use efficiency of new rice varieties released in Egypt.

\section{Material and Methods}

\subsection{Soil characteristics}

Soil samples for the experiment were obtained at a depth of $0-30 \mathrm{~cm}$ from rice research and training center experimental farm, Sakha, Kafr El Sheikh, Egypt. The collected samples were air-dried, crushed thoroughly, sieved through a 2-mm sieve and physical and chemical characterization obtained through laboratory analysis (Table 1). The $\mathrm{pH}$ and electrical conductivity (EC) of the soil samples were estimated using the $\mathrm{pH}$-meter and electrical conductivity meter respectively. Particle size distribution was also assessed (Gee and Bauder 1996: 377382). Cations and anions were measured using standard methods (Hossner 1996).

\subsection{Field experiment design}

Field experiments were conducted at experimental farm of rice research and training center, Egypt during 2016 and 2017 rice-growing seasons. Newly released varieties Sakha 108 and some promising lines GZ9399-4-1-1-3-2-2,
GZ10101-5-1-1-1 and GZ10154-3-1-1-1 were evaluated in this trial. Nitrogen fertilizer was applied at different five levels $\left(0,55,110,165\right.$ and $\left.220 \mathrm{~kg} \mathrm{~N}^{-1}\right)$ as urea form. Nitrogen fertilizer was applied as split method, in two equal doses as follows i.e., the first dose was incorporated into dry soil before flooding and the second dose was applied after 30 days of transplanting. The split plot experimental design, with four repeats, was used for this study. The newly released varieties were subjected in main plots, while the sub-plots were subjected to the different nitrogen levels. The seed rate for all the sown genotypes was $96 \mathrm{~kg} \mathrm{ha}^{-1}$ in both seasons. The germination percentage of all the genotype seeds was $90 \%$. Prior to sowing, clean seeds were soaked in tap water for 24 hours and incubated for 48 hours. After the seed treatment, pre-germinated seeds were broadcasted in the nursery on $5^{\text {th }}$ and $8^{\text {th }}$ of May in 2016 and 2017, respectively. Seedling of 30 days old age (3-4 seedling hill-1) was transplanted at $20 \mathrm{~cm} \times 20 \mathrm{~cm}$ distance between hills and rows. The plot size was $4 \mathrm{~m} \mathrm{x}$ $3 \mathrm{~m}$. Phosphorus fertilizer at the rate of $36 \mathrm{~kg} \mathrm{P}_{2} \mathrm{O}_{5}$ ha $^{-1}$ was applied as basal application during soil preparation. Zinc was applied in the form of Zinc sulphate (containing 22\% $\mathrm{Zn}$ ) at the rate of $24 \mathrm{~kg} \mathrm{ha}^{-1}$ just before transplanting. After transplantation, $5 \mathrm{~cm}$ water depth was maintained in all plots for whole crop season and weeds were chemically eradicated as per recommendation. Insects and diseases was intensively controlled through the rice season to avoid any yield loss. All recommended agronomic practices were followed as per need. Plots were drained with water before 10 days of harvesting for ease of handling crop harvest and days to complete heading was recorded. Plant height at maturity was measured form 5 hills per plot from the soil surface to the tip of the tallest panicle of each hill. Grain yield was determined from $5 \mathrm{~m}^{2}$ in each plot and adjusted to $14 \%$ moisture content. Number of panicles per hill was counted for 5 hills from middle rows in each plot. Number of filled and unfilled grains per panicle was counted of five main panicles in each plot. Panicle length $(\mathrm{cm})$ from panicle base up to a piculus of the upper most spikelet of the panicle from five panicles, 1000-grain weight (g) and grain yield t ha ${ }^{-1}$, were estimated according to IRRI (1996). Agronomic efficiency (AE) was calculated according to Fageria et al. (1997):

Table 1: Soil characteristics of the experimental site

\begin{tabular}{|c|c|c|c|c|c|c|c|c|c|c|c|c|}
\hline \multirow[t]{2}{*}{$\mathrm{pH}$} & \multirow{2}{*}{$\begin{array}{l}E C \\
\left(d S ~ m^{-1}\right)\end{array}$} & \multicolumn{4}{|c|}{ Cations (meq L-1) } & \multicolumn{4}{|c|}{ Anions (meq $\mathrm{L}^{-1}$ ) } & \multicolumn{3}{|c|}{ Particles size \% } \\
\hline & & $\mathrm{Ca}^{2+}$ & $\mathbf{M g}^{2+}$ & $\mathrm{Na}^{+}$ & $\mathbf{K}^{+}$ & $\mathrm{Cl}^{-}$ & $\mathrm{HCO}_{3}^{-}$ & $\mathrm{CO}_{3}{ }^{2-}$ & $\mathrm{SO}_{4}^{2-}$ & Sand & Silt & Clay \\
\hline 7.95 & 1.85 & 2.85 & 1.75 & 3.25 & 2.50 & 2.90 & 2.50 & 3.50 & 1.48 & 16.8 & 34.3 & 48.9 \\
\hline
\end{tabular}

EC, Electrical Cconductivity. 
Agronomic efficiency $(A E)=\left(G_{f}-G_{u} / N_{a}\right) \mathrm{kg}$ rice grain $/ \mathrm{kg}$ $\mathrm{N}$ fertilizer applied

Where $G_{f}$ is the grain yield of the fertilized plot $(\mathrm{kg}), G_{u}$ is the grain yield of the unfertilized plot $(\mathrm{kg})$, and $\mathrm{N}_{\mathrm{a}}$ is the rate of applied $\mathrm{N}$ fertilizer $(\mathrm{kg})$.

\subsection{Statistical analysis}

All data recorded were statistically analyzed by following the procedure described by Gomez and Gomez (1984) using the IRRISTAT computer software.

Ethical approval: The conducted research is not related to either human or animal use.

\section{Results and Discussion}

\subsection{Days to complete heading}

Rice genotypes differed significantly in their days to complete heading (Table 2). GZ10154 was early maturing compared with the other varieties, meanwhile, the Sakha 108 recorded the maximum number of days to complete heading. This is mainly due to the differences in genetic background among the rice cultivars. Our results are in line with that of Sedeek et al. (2009) and Abd Alla (1996) who reported that the differences among the rice varieties in number of days to complete heading may be attributed to the nature of the varieties, which is mainly affected by genetic and partially by the environmental factors such as fertilizer, soil condition and weather. Regarding the effect of nitrogen levels, this study revealed that gradual increase in nitrogen fertilizer rate ( 0 to $220 \mathrm{~kg} \mathrm{~N} \mathrm{ha}^{-1}$ ) significantly enhanced the number of days to complete heading for all rice varieties in both seasons of investigation (Table 2). Days to complete heading increased with increasing $\mathrm{N}$ rate up to $220 \mathrm{~kg} \mathrm{~N}$ ha $^{-1}$ (Table 2). The minimum number of days to complete heading were obtained by zero nitrogen application. This is mainly due to the role of nitrogen on improving rice growth, internode elongation, photosynthesis and metabolism and assimilation of production, enhance to delay the heading of rice varieties (Noor 2017). The findings of Abd Alla (1996) and Metwally et al. (2011) also illustrate the similar results. The interaction effect of rice genotypes and nitrogen rates on days to complete heading was highly significant in both seasons (Figure 1). The maximum number of days to complete heading were recorded for Sakha 108 when $220 \mathrm{~kg} \mathrm{~N} \mathrm{ha}^{-1}$ was applied, while the minimum number of days to complete heading were recorded with GZ9399 when no N fertilizer was applied. The rice varieties varied significantly in plant height, Sakha 108 variety recorded the tallest plants and it was statistically similar with GZ9399 in the second season, while, GZ10101 gave the shortest plants in both seasons. This variation in plant height can be explained by genetic makeup of studied lines. By increasing the nitrogen levels, significantly augmented plant height for rice varieties. Nitrogen application rate of $220 \mathrm{~kg} \mathrm{~N} \mathrm{ha}^{-1}$ resulted in tallest plant $(94.08$ and $94.67 \mathrm{~cm})$ in both seasons. This might be due to the

Table 2: Days to complete heading, plant height, panicle length and number of panicles hill-1 ${ }^{-1}$ rice genotype as affected by nitrogen levels in 2016 and 2017 growing seasons

\begin{tabular}{|c|c|c|c|c|c|c|c|c|}
\hline \multirow[t]{2}{*}{ Treatment } & \multicolumn{2}{|c|}{ Days for heading } & \multicolumn{2}{|c|}{ Plant height (cm) } & \multicolumn{2}{|c|}{ Panicle length $(\mathrm{cm})$} & \multicolumn{2}{|c|}{ No of panicles hill ${ }^{-1}$} \\
\hline & 2016 & 2017 & 2016 & 2017 & 2016 & 2017 & 2016 & 2017 \\
\hline \multicolumn{9}{|l|}{ Genotype } \\
\hline Sakha 108 & 98.60 & 98.93 & 91.73 & 91.64 & 21.70 & 21.33 & 16.20 & 16.00 \\
\hline GZ9399 & 85.87 & 85.93 & 89.00 & 89.72 & 22.84 & 23.22 & 14.73 & 14.72 \\
\hline GZ10101 & 91.00 & 91.07 & 88.00 & 87.60 & 21.86 & 21.49 & 15.33 & 15.26 \\
\hline GZ10154 & 87.33 & 87.67 & 89.27 & 89.00 & 21.00 & 21.35 & 16.53 & 16.12 \\
\hline LSD 5\% & 0.15 & 0.24 & 0.59 & 2.16 & 0.68 & 0.63 & 0.42 & 0.81 \\
\hline \multicolumn{9}{|l|}{ N kg ha-1 } \\
\hline Control & 87.00 & 87.17 & 85.50 & 85.15 & 20.30 & 20.28 & 9.08 & 8.88 \\
\hline 55 & 88.75 & 89.00 & 86.92 & 86.75 & 21.01 & 20.82 & 12.83 & 13.00 \\
\hline 110 & 91.17 & 90.92 & 88.50 & 88.80 & 22.18 & 22.18 & 16.42 & 16.20 \\
\hline 165 & 92.50 & 92.75 & 92.25 & 92.25 & 22.78 & 22.78 & 18.500 & 18.05 \\
\hline 220 & 94.08 & 94.67 & 94.33 & 94.50 & 23.01 & 23.17 & 21.67 & 21.50 \\
\hline LSD 5\% & 0.15 & 0.37 & 0.78 & 1.62 & 0.64 & 0.49 & 0.36 & 0.64 \\
\hline Interaction & $\star \star$ & $\star \star$ & NS & NS & NS & NS & $\star \star$ & $\star \star$ \\
\hline
\end{tabular}




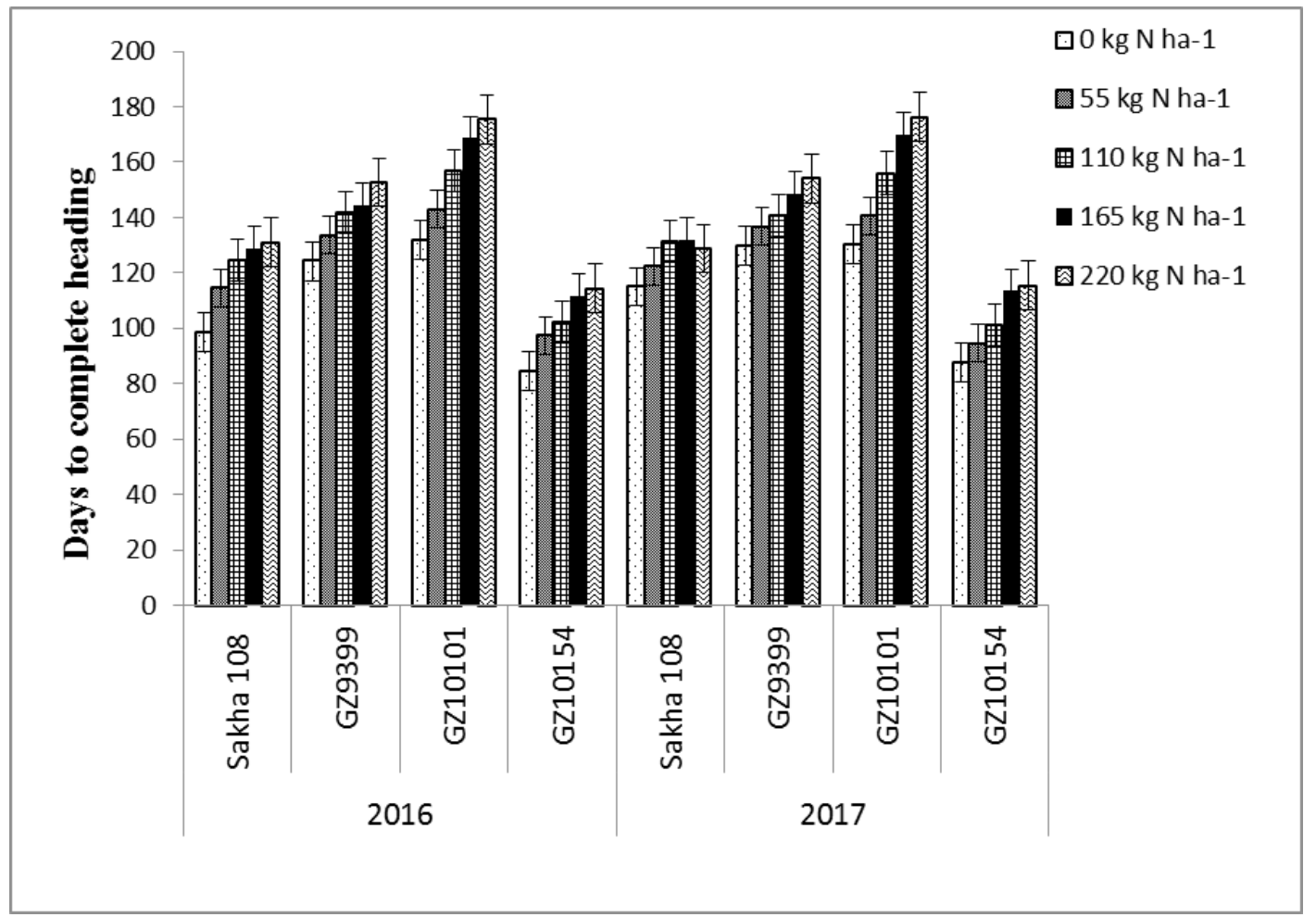

Figure 1: Days to complete heading as affected by interaction between rice genotypes and N levels in 2016 and 2017 seasons. Vertical bars represent \pm standard error $(S E, \mathrm{n}=4)$

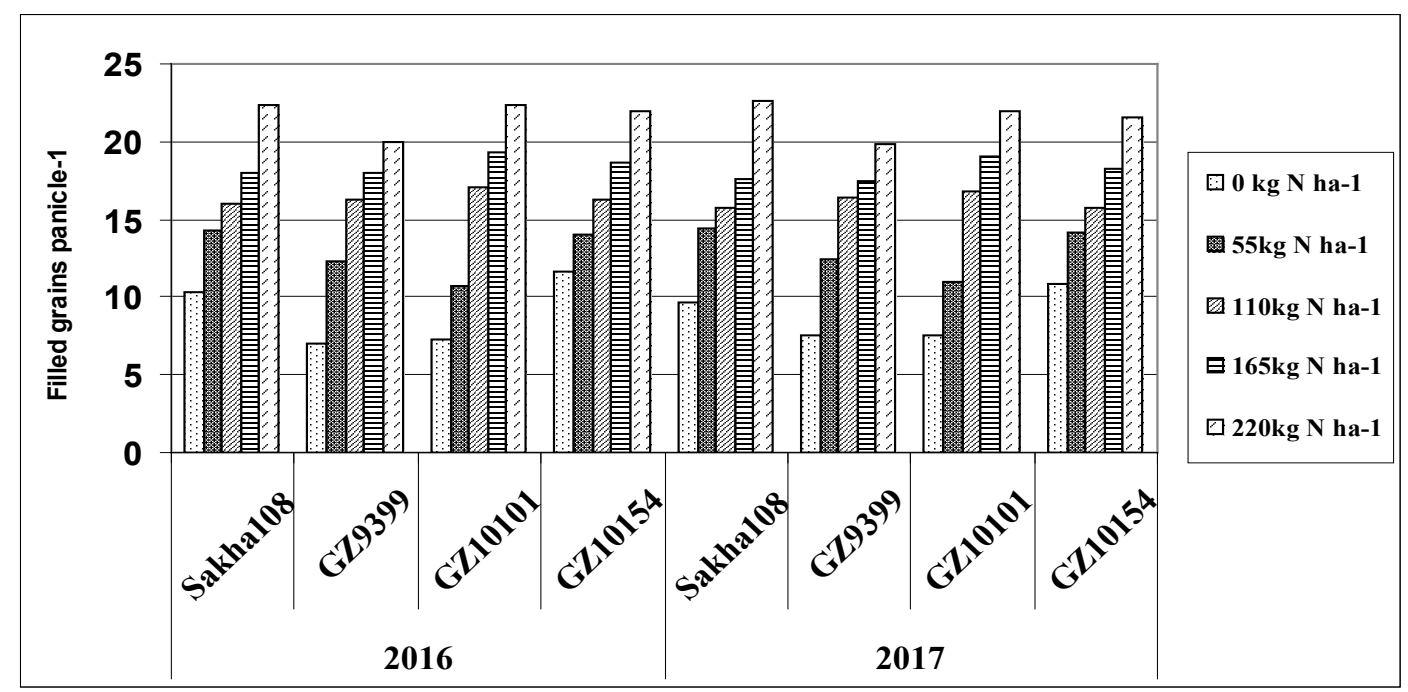

Figure 2: Number of panicles per hill as affected by interaction between rice genotypes and N levels in 2016 and 2017 seasons

role of nitrogen in improving rice growth, internode elongation, photosynthesis and metabolism and assimilated production. These results are similar with those of Metwally et al. (2011). Regarding the interaction between varieties and nitrogen levels, plant height was not significant.

\subsection{Panicle length}

Regarding, the panicle length, GZ9399 showed the maximum panicle length. On the other hand, the other genotypes showed the shortest panicle. Panicle length increased significantly with increased levels of nitrogen 
application (Table 2). These results are similar to those obtained by Metwally et al. (2011). Metwally et al. (2017) and Yoseftabar (2013) also reported the maximum panicle length at highest level of nitrogen application. The interaction between rice varieties and nitrogen rates for this trait was not significant in both seasons.

\subsection{Number of panicles}

Number of panicles per hill, was markedly influenced by different rice genotypes and various nitrogen levels application as well as their interaction (Table 2). The rice varieties differed significantly in their abilities in producing panicles/hill. Among the genotypes, Sakha 108 and GZ10154 gave the highest values of number of panicles/hill while, GZ9399 recorded the lowest values in both seasons. This might be due to the differences in the genetic background among rice genotypes. The high rate of $\mathrm{N}\left(220 \mathrm{~kg} \mathrm{ha}^{-1}\right)$ recorded maximum counts of panicles/hill, while the control showed minimum counts of panicles/hill. Metwally et al. (2017) also reported that nitrogen application of $165 \mathrm{~kg} \mathrm{~N} \mathrm{ha}^{-1}$ improved the counts of panicles/hill. Rice varieties responded significantly to nitrogen levels, where the counts of panicles/hill were increased significantly with increasing nitrogen levels from 0 to $220 \mathrm{~kg} \mathrm{~N} \mathrm{ha}^{-1}$ for all rice varieties (Table 2). The role of nitrogen in the stimulation of cell division may have led to more panicle formation during the productive stage in rice. Abd EL-Hamed (2002) and Sorour et al.
(2016) reported similar results. Regarding the interaction effect of rice genotypes and nitrogen levels, Sakha 108 and GZ10101 produced the maximum number of panicle at the rate of $220 \mathrm{~kg} \mathrm{~N} \mathrm{ha}^{-1}$ applied in both seasons, while the minimum number of panicles per hill were produced by GZ9399 or GZ10101 under control treatment in 2016 and 2017 growing seasons, respectively.

\subsection{Number of filled grains}

The GZ10101 recorded maximum number of filled grains per panicle, while, GZ10154 recorded the lowest number of filled grains in the both growing seasons. Regarding nitrogen levels effect, increased rate of nitrogen from 0 to $220 \mathrm{~kg} \mathrm{~N} \mathrm{ha}^{-1}$ significantly enhanced the number of filled grains per panicle for all rice genotypes. Similar results have been obtained by Abd EL-Hamed (2002) and Sorour et al. (2016). The rice genotypes differed significantly in their response to nitrogen levels. This might be due to source sink interaction, meaning maximum proportion of $\mathrm{N}$ source is used to produce maximum spikelets per panicle and grain filling (Noor 2017). The ore the number of spikeletes produced, the less will be the number of filled grains at any rate of nitrogen application. Interaction effect was significant for rice genotypes and nitrogen fertilizer levels for filled grains per panicle (Figure 3). The application rate of $220 \mathrm{~kg} \mathrm{~N} \mathrm{ha}^{-1}$, recorded the maximum number of filled grains per panicle followed by $165 \mathrm{~kg} \mathrm{~N}$ ha $^{-1}$ treatment for all genotypes.

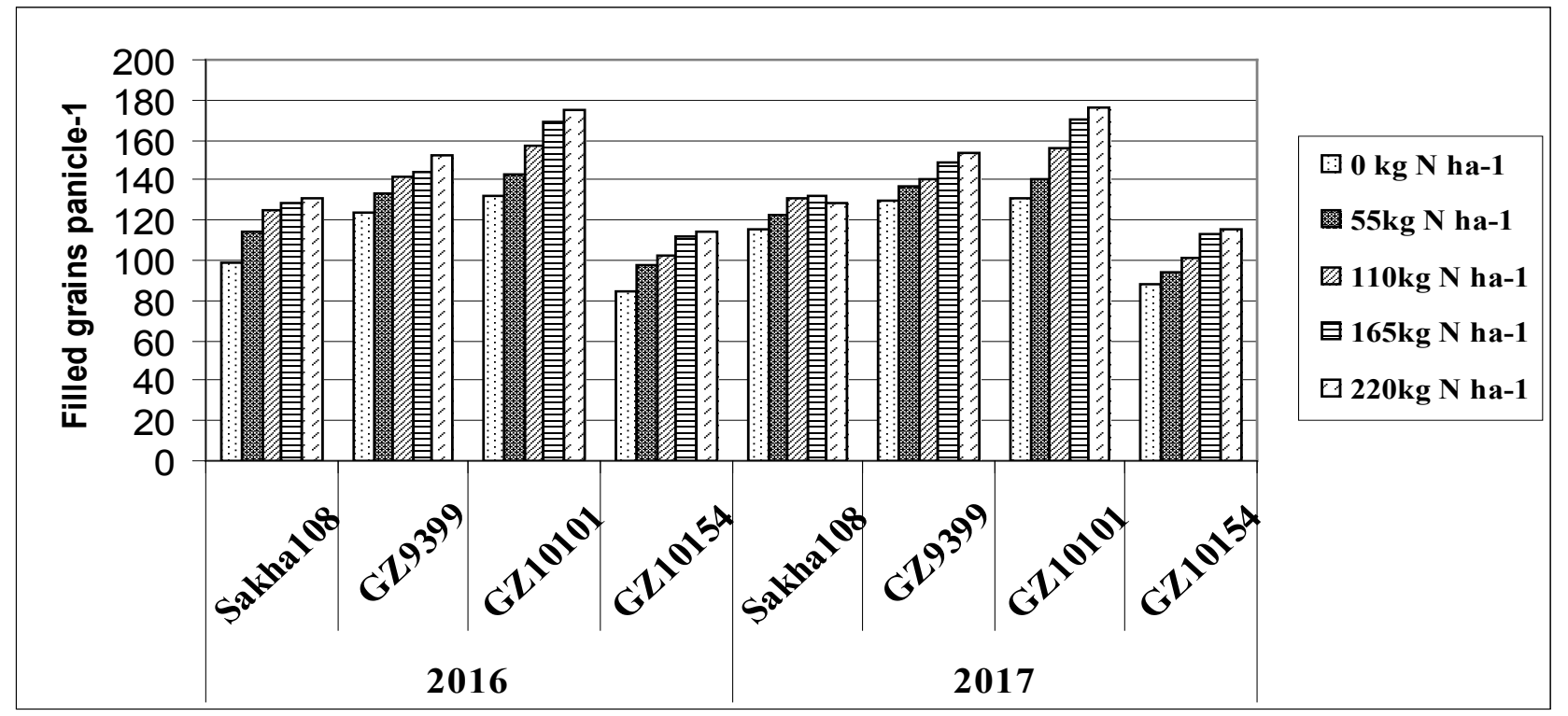

Figure 3: Filled grains per panicle as affected by interaction between rice genotypes and N levels in 2016 and 2017 seasons 


\subsection{Number of unfilled grains}

The rice genotypes GZ9399 recorded the maximum number of unfilled grains per panicle; on the other hand, the rice genotypes, GZ10154 exhibited the lowest number (Table 3). With increased rate of nitrogen application, a significant increase in number of unfilled grains per panicle for all rice genotypes was observed. This increase in number of unfilled grains might be associated with production of more spikelets per plant and photoassimilation. These results are similar to those obtained by Metwally et al. (2010); Ghoneim (2014). The interaction between rice genotypes and nitrogen levels on quantity of unfilled grains per panicle was not significant.

\subsection{0-grain weight}

For 1000-grain weight, Sakha 108 exhibited the higher 1000-grain weight in both years while GZ10101 gave the lowest values of 1000-grain weight. Nitrogen fertilizer application significantly increased the 1000 grain`s weight. The possible reason behind this may be due to production of higher number of spikelets per panicle in the plants fertilized by nitrogen. This caused the high sink capacity as compared to limited respective source, therefore, the grain filling was more and consequently the grain of weight was high. The promoting effects of nitrogen on 1000-grain weight were reported by Metwally et al. (2010), Ghanbari-Malidareh (2011) and Sorour et al. (2016).

\subsection{Grain yield}

There were significant differences among various rice genotypes in grain yield produced. The rice variety Sakha 108, recorded the maximum grain yield while GZ10154 and GZ10101 gave the lowest grain yield in both seasons (Table 3). Increased nitrogen rates from 0 to $220 \mathrm{~kg} \mathrm{~N}$ ha ${ }^{-1}$ significantly enhanced the grain yield, whereas the rate of nitrogen of $220 \mathrm{~kg} \mathrm{~N} \mathrm{ha}^{-1}$ showed the highest values of grain yield followed by $165 \mathrm{~kg} \mathrm{~N} \mathrm{ha}^{-1}$ while, the minimum grain yield was obtained without nitrogen application (Table 3). The increase in grain yield might be due to nitrogen application enhancing the dry matter production, improving rice growth rate, promoting elongation of internodes and activity of growth hormones like gibberellins. These results are supported by the findings of Singh et al. (2000). Interaction between nitrogen levels and the promising lines for grain yield (Figure 4), illustrated that the maximum grain yield for the rice varieties was obtained from $220 \mathrm{~kg} \mathrm{~N} \mathrm{ha}^{-1}$, followed by $165 \mathrm{~kg} \mathrm{~N} \mathrm{ha}^{-1}$, while the minimum value of grain yield was obtained without nitrogen application. The performance of rice genotypes significantly varied according to nitrogen application. Sakha 108 recorded the highest straw yield when nitrogen applied at $220 \mathrm{~kg} \mathrm{~N}^{-1}$ while, the minimum grain yield was recorded by GZ10101 in both seasons. It is worth to notice that the optimum grain yield form GZ9399 was obtained at the level of 165 kg N ha ${ }^{-1}$. The studies by Koutroubas and Ntanos (2003) and Gharib et al. (2011) also reported that increasing nitrogen level up to $150 \mathrm{~kg} \mathrm{~N}^{-1}$ enhanced grain yield.

Table 3: Filled grains panicle ${ }^{-1}$, unfilled grains panicle ${ }^{-1}, 1000$ grain weight and grain yield t ha ${ }^{-1}$ of rice genotype as affected by nitrogen levels in 2016 and 2017 seasons

\begin{tabular}{|c|c|c|c|c|c|c|c|c|}
\hline \multirow[t]{2}{*}{ Treatment } & \multicolumn{2}{|c|}{ Filled grains panicle ${ }^{-1}$} & \multicolumn{2}{|c|}{ Unfilled grains panicle $^{-1}$} & \multicolumn{2}{|c|}{1000 grain weight (g) } & \multicolumn{2}{|c|}{ Grain yield (t ha-1) } \\
\hline & 2016 & 2017 & 2016 & 2017 & 2016 & 2017 & 2016 & 2017 \\
\hline \multicolumn{9}{|l|}{ Genotype } \\
\hline Sakha 108 & 119.60 & 125.88 & 11.27 & 11.68 & 29.57 & 30.30 & 8.11 & 8.05 \\
\hline GZ9399 & 139.33 & 142.00 & 21.47 & 21.48 & 26.31 & 26.20 & 7.57 & 7.63 \\
\hline GZ10101 & 155.20 & 154.64 & 13.73 & 14.13 & 25.90 & 25.96 & 6.27 & 6.29 \\
\hline GZ10154 & 102.00 & 102.49 & 9.93 & 10.00 & 28.30 & 28.39 & 6.13 & 6.25 \\
\hline LSD 5\% & 3.96 & 4.04 & 0.68 & 0.60 & 0.61 & 0.33 & 0.037 & 0.062 \\
\hline \multicolumn{9}{|l|}{ N kg ha-1 } \\
\hline Control & 109.83 & 115.80 & 11.67 & 11.75 & 26.68 & 26.66 & 4.77 & 4.76 \\
\hline 55 & 122.17 & 123.60 & 13.42 & 13.20 & 27.10 & 27.19 & 5.15 & 5.20 \\
\hline 110 & 131.42 & 132.60 & 13.67 & 14.02 & 27.44 & 27.70 & 6.15 & 6.27 \\
\hline 165 & 138.42 & 141.02 & 14.92 & 15.50 & 27.86 & 28.11 & 9.44 & 9.42 \\
\hline 220 & 143.33 & 143.60 & 16.83 & 17.15 & 28.52 & 28.91 & 9.59 & 9.64 \\
\hline LSD 5\% & 3.37 & 3.24 & 0.66 & 0.50 & 0.45 & 0.45 & 0.091 & 0.097 \\
\hline Interaction & * & ** & NS & NS & NS & NS & $\star \star$ & $\star \star$ \\
\hline
\end{tabular}


The increased grain yields could be attributed to the role of nitrogen in enhancing grain yield components i.e., counts of panicles per hill, panicle length, quantity of filled grains per panicle and panicle weight.

\subsection{Agronomic Nitrogen Use Efficiency}

Agronomic efficiency (AE) was significantly affected by nitrogen application (Figure 5) and increased with increasing $\mathrm{N}$ levels up to $165 \mathrm{~kg} \mathrm{~N} \mathrm{ha}^{-1}$. Whereas reduction in $\mathrm{AE}$ has been observed by further uplift in $\mathrm{N}$ application of $165 \mathrm{up}$ to $220 \mathrm{~kg} \mathrm{~N} \mathrm{ha}^{-1}$. Saleque et al. (2004) reported that $\mathrm{AE}$ is usually greater at low dose of $\mathrm{N}$ fertilizer application. Agronomic efficiency (AE) differed in different genotypes and it ranged from 3.63 to 32.91 and from 2.72 to $34.12 \mathrm{~kg}$ grain yield produced per $\mathrm{kg}$ of nitrogen applied in the first and second season, respectively. Across all nitrogen levels, GZ9399 recorded the maximum values of AE for treatment of $165 \mathrm{~kg} \mathrm{~N} \mathrm{ha}^{-1}$ in both seasons. Many scientists have also reported variations in nitrogen use efficiency among different genotypes of lowland rice (Fageria and

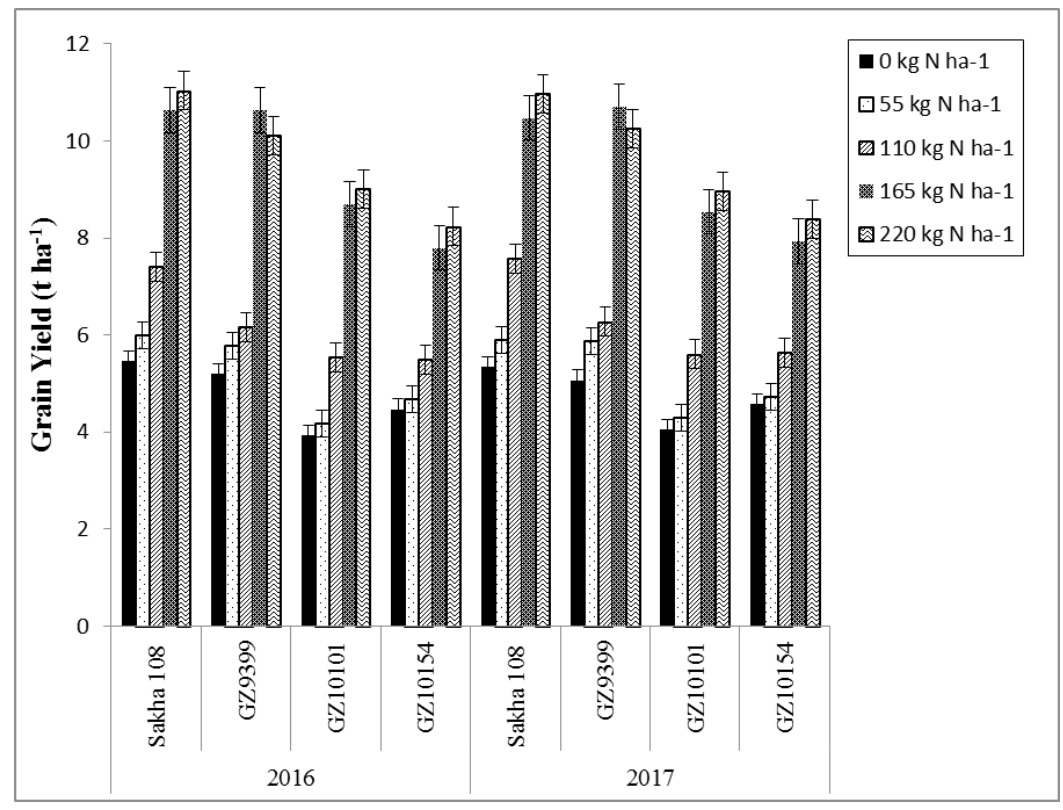

Figure 4: Grain yield ( $\left(\mathrm{ha}^{-1}\right)$ as affected by interaction between rice genotypes and $\mathrm{N}$ levels in 2016 and 2017 seasons. Vertical bars represent \pm standard error $(n=4)$

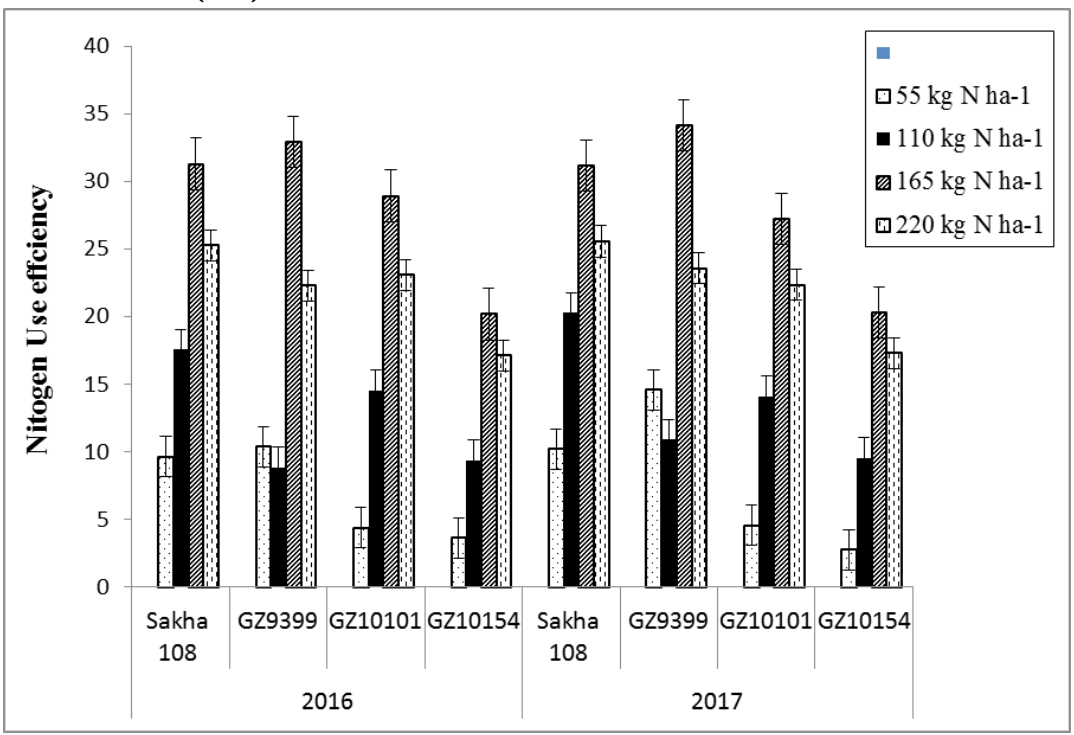

Fig. 5. Effects of interaction between rice genotypes and N levels on nitrogen use efficiency during the 2016 and 2017 growing seasons. Vertical bars represent \pm standard error $(n=4)$. 
Baligar 2003). Such variations may be attributed due to genetic factors, biochemical and physiological processes such as translocation, assimilation and $\mathrm{N}$ remobilization (Isfan 1993; Fageria and Baligar 2003).

\section{Conclusion}

Application of appropriate levels of $\mathrm{N}$ fertilizers is one of important factor to increase $\mathrm{N}$ use efficiency by rice cultivars. Improve of $\mathrm{N}$ use efficiency can be achieved through optimum $\mathrm{N}$ application rates. The results of this study indicated that the increased nitrogen rates up to $220 \mathrm{~kg} \mathrm{~N}$ ha $^{-1}$ significantly enhanced the grain yield and the yield components. Agronomic efficiency varied significantly among rice genotypes. The optimum $\mathrm{N}$ application rates for newly released Egyptian rice genotypes is not only essential for producing higher rice yield, but also for improving soil fertility.

Conflict of interest: Authors state no conflict of interest.

\section{References}

Abd Alla A.B., Effect of some cultural treatments on rice, M.Sc. Thesis, Zagazig University, Zagazig, Egypt, 1996

Abd El-Hamed M.I., Agricultural studies on rice, M.Sc. Thesis, Kafr El Sheikh, Tanta University, Kafr El Sheikh, Egypt, 2002

Ebaid R.A., Ghanem S.A., Productivity of Giza 177 rice variety grown after different winter crops and fertilized with different nitrogen levels, Egypt J. Agric. Res., 2000, 78, 717-731

EL-Batal M.A., Abd EL-Gawad M.H., Abdo F.A., EL-Set A., EL-Aziz A., Uniconazole application as anti-lodging for rice plants fertilized with high nitrogen rate, Zagazig J. Agric., Res., 2004, 31, 473-490

Fageria N.K., Baligar V.C. Methodology for evaluation of lowland rice genotypes for nitrogen use efficiency, J Plant Nutr., 2003, 26, 1315-1333

Fageria N.K., Baligar V.C., Jones C.A., Growth and Mineral Nutrition of Field Crops, 2nd ed., Marcel Dekker, Inc., New York, 2007

Fageria N.K., Baligar V.C., Li Y.C., The role of nutrient efficient plants in improving crop yields in the twenty first century, J. Plant Nutr., 2008, 31, 1121-1157

FAO, Selected indicators of FAO in Asia-Pacific region corporate document repository, Food and Agriculture Organization, 2004

Gee G.W., Bauder J.W., Particle Size Analysis, 3rd ed., In: Klute A. Ed., Methods of soil Analysis, Part 1: Physical and Mineralogical Methods, S.S.S.A. and American Society of Agronomy, Madison, WI, 1996

Ghanbari-Malidareh A., Silicon application and nitrogen on yield and yield Components in rice (Oryza sativa L.) in two irrigation systems, WASET, 2011, 74, 88-95

Gharib H.S., Metwally T.F., Naeem S.S., Gewaily E.E., Influence of some stimulating compounds and nitrogen fertilizer levels on growth and yield of hybrid rice, Zagazig J. Agric. Res., 2011, 38, 1-21

Ghoneim A.M., Nitrogen and carbon uptake by some Rice cultivars from ${ }^{15} \mathrm{NH}_{4} \mathrm{Cl}$ and ${ }^{13} \mathrm{C}-\mathrm{U}$-glucose labeling fertilizer, Int. J. Agron. Agric. Res., 2014, 4, 20-27

Ghoneim A.M., Ebid A.E., Combined effects of soil water regimes and rice straw incorporation into the soil on ${ }^{15} \mathrm{~N}, \mathrm{P}, \mathrm{K}$ uptake, Rice yield and selected soil properties, Int. J. Plant Soil Sci., 2015, 5, 339-349

Gomez K.A., Gomez A.A., Statistical procedures for agricultural research, 2nd ed., John Wiley and Sons, 1984

Hossner L.R., Dissolution for Total Elemental Analysis, In: Bigham J.M (Ed.), Methods of soil analysis, Part 3. Chemical Methods, Soil Science Society of America, Inc., Madison, Wisconsin, 1996

Standard Evaluation System for rice, 3rd ed., International Rice Research Institute, Los Banos, 1996

Isfan D., Genotypic variability for physiological efficiency index of nitrogen in oats, Plant Soil, 1993, 154, 53-59

Koutroubas S.D., Ntanos D.A., Genotypic differences for grain yield and nitrogen utilization in Indica and Japonica rice under Mediterranean condition, Field Crops Res., 2003, 83, 251-260

Manjappa G.U., Shailaja H., Association analysis of drought and yield related traits in F2 population of Moroberekan/IR64 rice cross under aerobic condition, Int. J. Agric. Sci. Res., 2014, 4, 79-88

Maske N.S., Borkar S.I., Rajgire H.J., Effect of nitrogen levels on growth, yield and grain quality of rice, J. Soil. Crop., 1997, 7, 83-89

Metwally T.F., Gewaily E.E, Naeem S.S., Nitrogen response curve and nitrogen use efficiency of Egyptian hybrid rice, J. Agric. Res. Kafer El-Sheikh Univ., 2011, 37, 73-84

Metwally T.F., Sedeek S.E.M., Abdelkhalik A.F., EL-Rewiny I.M., Metwali E.M.R., Genetic Behaviour of some rice (Oryza sativa L.) genotypes under different treatments of nitrogen levels, American-Eurasian J. Agric.\& Environ. Sci., 2010, 8, 27-34

Metwally T.F., Gabr W.E., Hashem I.M., Growth performance of genotypes at suboptimal level of nitrogen fertilizer and affect of rice blast and white tip nematode diseases. Egy. J. Plant Pro. Res., 2017, 5, 47-74

Noor M.A., Nitrogen management and regulation for optimum NUE in maize-A mini review, Soil Crop Sci., 2017, https://www. cogentoa.com/article/10.1080/23311932.2017.1348214

Sachiko N., Kazunobu T., Yoshimichi F., Genetic variations in dry matter production and physiological nitrogen use efficiency in rice (Oryza Sativa L.) varieties, Breed. Sci., 2009, 59, 269-276

Salem A.K.M., Effect of nitrogen levels, plant spacing and time of farmyard manure application on the productivity of rice, J. Appl. Sci. Res, 2006, 2, 980-987

Saleque M.A., Naher U.A., Choudhury N.N., Hossain A.T., Varietyspecific nitrogen fertilizer recommendation for lowland rice, Commun. Soil Sci. Plant. Anal., 2004, 35, 1891-1903

Sedeek S.E.M., Hammoud S.A.A., Ammar M.H., Metwally T.F., Genetic variability, heritability, genetic advance and cluster analysis for some physiological traits and grain yield and its components in rice (Oryza Sativa L.), J. Agric. Res. Kafr El-Sheikh Univ., 2009, 35, 858-878

Shaiful Islam Md., Hasanuzzaman M., Rokonuzzaman M., Nahard K., Effect of split application of nitrogen fertilizer on morpho- 
physiological parameters of rice genotypes. Int. J. Plant Prod., 209, 3, 51-62

Singh M.K., Thakur R., Verma U.N., Upasani R.R., Effect of planting time and nitrogen on production potential of Basmati rice (Oryza sativa L.) cultivars in Bihar Plateay, Ind. J. Agronomy, 2000, 45, 300-303

Sorour F.A., Ragab A.Y., Metwally T.F., Shafik A.A., Effect of planting methods and nitrogen fertilizer rates on the productivity of rice (Oryza sativa L.). J. Agric., Res., Kafr EL-Sheikh Univ., J. Plant Prod., 2016, 42, 207-216

Wattoo F.M., Rana R.M., Fiaz S., Zafar S.A., Noor M.A., Hassan H.M., et al., Identification of Drought Tolerant Maize Genotypes and
Seedling based Morpho-Physiological Selection Indices for Crop Improvement, Sains Malays., 2018, 47, 295-302

Yoseftabar S., Effect nitrogen management on panicle structure and yield in rice (Oryza sativa L.), Intl. J. Agri. Crop. Sci., 2013, 5, 1224-1227

Zafar S.A., Noor M.A., Waqas M.A., Wang X., Shaheen T., Raza M., et al., Temperature extremes in cotton production and mitigation strategies; In: Rahman M.U., Zafar Y., (Eds.), Past, Present and Future Trends in Cotton Breeding, IntechOpen, Rijeka, 2018 